ny apologetycznym. Stara się mianowicie wtajemniczyć początkujących badaczy w podstawowe zasady i w zakres metody historycznej, następnie wywodzi genezę owej metody i poucza o sposobach jej stosowania do chrystologii nowo-testamentowej; czyni to zaś w sposób wysoce oryginalny, lecz zjednywający sobie przekonanie czytelnika. Ewangelie - dowodzi autor, - nie stanowią wystarczającego materiału do zbudowania wyczerpu ącej biografii Jezuia; przekazują one jedynie „euangelion“, to jest dobrą wieść, że Jezus z Nazaretu jest Chrystusem. Domagają się od ludzi wiary, w szczególności wiary w dziewicze Poczęcie i w Zmartwychwstanie Jezusa oraz - Jego pos’annictwo mesjańskie. Istotą nauki Jezusowej, tak, jak ją odtwarzają Synoptycy, jest wieść, że oto teraz zbawienie dane jest ludziom, jako dar Boga, dany laską tym wszystkim, którzy żałują za swe grzechy i okazują braciom swoim odblask miłości Bożej. Pierwsi Apostolowie - pisze autor, - napelnieni Duchem świętym, głosili ",Kerygma“ chrześcijańskie, lecz głosząc je, napotykali zarzuty, wymagające odparcia, względnie zagađnienia nowe, które należało rozwiązać; praca nad tym stanowi'a nową próbę ich wiary i ich nadziei. Dođamy od siebie, że ów trud apostolski, o którym mowa w tej chwili, był równ:eż i przede wszystkim, próbą miłości pierwszych głosicieli S’owa Bożego i pierwszych jego wykładowców; wiara bowiem wzywa mądrości, nadzieja przygotowu:e dla niej odpowiednie miejsce w duszy ludzkiej, ale tylko miłość zdobywa ją, upewnia i utrwala. Gdzie nie ma miłości, tam nie ma i mądrości. Innymi słowy: wszelka mądrość pochodzi z milości, z niej też czerpie swoją pewność i swoje trwanie.

Wedle Sandersa praca oraz trud apostolski, podjęty w celu apologetycznego i dogmatycznego ukrzepienia nauki Chrystusowej byl zaczynem teologii, którą potężnymi wzniesieniami myśli jął rzeźbić święty Paweł - w Liście do żydów, - i święty Jan, obok innych siewców dobrej wieści.

Krakow

KS. WEADYSEAW SMEREKA

\title{
DEKRET GENERALNY O UPROSZCZENIU RUBRYK
}

\section{Wstęp w skrócie :}

Liczne zajęcia i prace ciążące na kapłanach pracujących zwłaszcza w dusźpasterstwie, staly się powodém próśb kierowanych przez niektórych ordynariuszy do St. Apostolskiej. by biorąc powyższe pod uwagę, uprościć przynajmniej i skrócić rubryki brewiarzowe.

Ojciec św. ustalił w tym celu spec alną komisję, która postanowiła zredukować i wprowadzić pewne zmiany, zatrzymując istniejące księgi liturgiczne, dokąd nie zostanie postanowione coś nowego co do samych

•) AAS 47 (1955), s. 218-224) oraz RBL (1954), s. 205-210.

Ruch Blblijny - II 
ksiąg. Następnie polecił Fapież Prefektowi Kongregacji SRC, ogłosić powyższe zmiany obowiązują od stycznia $1956 \mathrm{r}$. oraz podać do publicznej wiadomości niniejszy dekret, jak również rubryki po przeprowadzonych poprawkach i zmianach, zaaprobowanych przez Ojca św.

Wydawcy zaaprobowani przez St. Ap. nie mogą wprowadzić żadnych zmian przy drukowaniu mszałów i brewiarzy.

Rzym 23. 3. 1955 Kard. Cicognani, Prefekt.

\section{O sprowadzeniu rubryk do prostszej formy}

Tyt. I. Normy ogólne.

1. Rozporządzenia, które następują, dotyczą rytu rzymskiego; te które nie są tu wyraźnie wymienione, pozostają niezmienione.

2. Pod nazwą kalendarza, należy rozumieć kalendarz dla całego Kościoła, jak i kalendarze partykułarne.

3. Normy, które są podane winny być zachowane tak w prywatnym jak i publicznym odmienianiu brewiarza, chyba że coś innege byłoby wyraźnie zastrzeżone.

4. Indulty patrykularne i zwyczaje „etiam speciali mentione dignae“, które sprzeciwiają się tym rozporządzeniom, uważać należy za wyraźnie odwołane (expresse revocatae).

Tyt. II. Zmiany $\mathrm{w}$ kalendarzu:

1. Stopień i ryt półzdwojony (semiduplex) - jest zniesiony.

2. Dni posiadające obecnie ryt półzdwojony - należy obchodzić ,ritu simplici" - wyjąwszy wigilię: Pentecostes; którą podnosi się do rytu zdwojonego.

a) Niedziele.

3. Niedziele Adwentu i Quadragesimy i inne, aż do niedzieli Przewodniej, a także i niedziela Zesł. Ducha św. - są rytu zdwojonego I klasy i nie ustępują jakimkolwiek świętom tak w okurencji, jak i konkurencji.

4. Kiedy w niedzielę II, III, IV Adwentu zbiegną się święta I k1., dozwolone są Msze św. "de festo" - z wyjątkiem konwentualnej.

5. Niedziele, które dotychczas były rytu półzdwojonego, zostały podniesione do rytu zdwojonego (dupl); Antyfon jednak nie zdwaja się (non duplicantur).

6. Oficjum i Msza św. "dominicae impeditae" - nie są antycypowane, ani też odkładane.

7. Jeżeli w niedzie nicy Panskiej (tituli vel mysterii Dni), święto zajmuje miejsce samej niedzieli, z której pozostaje tylko komemoracja. 

b) Wigilie.

8. Uprzywilejowanymi wigiliami są: wigilia B. Narodzenia i Zesłania Ducha sw.

9. Wigilie wspólne: wigilia Wniebowstąpienia, Wniebowzięcía N.M.P. sw. Jana Chrzciciela, sw. Ap. Piotra i Pawła, sw. Wawrzyńca. Wszystkie inne wigilie, także te, które wymieniają kalendarzo partykularne, sa zniesione.

10. Wigilie wspólne, które zbiegają się z niedzielą nie sa antycypowane, lecz opuszcza się je.

c) Oktawy:

11. Obchodzone są tylko oktawy: B. Narodzenia, Wielkanocy i Zesłania Ducha Sw. Znosi się wszystkie inne przypadiające w kalen darzu powszechnym i partykularnych.

12. Dni w czasie oktawy Wielkanocy i Zesłania Ducha śs. - są rytu zơwojonego, są przed jakimikolwiek swiętami i nie dopuszczaja kommemoracji.

13. Dni w czasie oktawy Bożego Narodzenia, są również podniesione do rytu zdwojonego, obchodzic należy je jak dotychczas.

14. W dniach od 2 do 5 stycznia, jeśli nie przypada jakies święto bierze się officjum ,de feria currenti ritu simplici“. Antyfony i psalmy do wszystkich godzin kan. i wersety nokturnów - „de currenti hebdomadae die, ut in psalterio". Reszta jak 1 stycznia, oprócz lekcji, które są „de Scriptura occur.". z własnymi responsoriami i odmawia się ,Te Deum“. Zakończenie hymnów i werset w ,resp. breve" w Prymie jak w B. Narodzenie.

Msza św., jak: 1 stycznia, ,sine Credo et sine Communicantes proprio". Wzbronione są Msze św. czytane, tak wotywne jak i cotidianae defunctorum.

15. Dni od 7 do 12 stycznia - zniesionej oktawy Objawienia Pańskiego, stają sie feriami ,per annum" (rytu prostego). W ofiçum antyfony i psalmy do wszystkich godzin i werset nokturnu z przypadającego dnia tygodnia, jak w psałterzu, reszta jak w święto Epifanii, oprócz lekcji, które są „de Scriptura occur.", z własnymi responsoriami i mówi się ,Te Deum".

Zakończenie hymnów i werset w Prymie z uroczystości Epifanii. Msza św. z Epifanil, bez Credo i "Communicantes proprio“.

Zabronione są Msze św. czytane, tak wotywne jak i „cotidianae defunct".

16. Dnia 13 stycznia obchodzi się: ,commemoratio Baptismatis D. N. Jesu Christi“ ryt zdwojony większy (dplx. m.). Oficjum i Msza \$w., tak jak teraz w czasie oktawy Epifanii. Jeżeliby powyższa uroczystość przypadła na niedzielę, ,tunc fit de festo $\mathbf{S}$. Famila, 
sine ulla commemoratione". W sobotę poprzedzającą bierze się początek I listu do Koryntian.

17. Dni od święta Wniebowstąpienia, aż do Wigilii Zielonych Swiąt wylącznie są feriami ,tempore Paschali“ (rytu prostego). W oficjum antyfony i psalmy do wszystkich godzin i wersety nokturnów bierze się $z$ przypadającego dnia tygndnia, jak $w$ brewiarzu, reszta jak w święto Wniebowstąpienia, oprócz lekcji, które są „de Scriptura..." $\mathrm{z}$ wlasnymi responsoriami.

Zakończenie hymnów i werset w Prymie ze święta Wniebowstapienia. Msza św. z tegoż święta, bez Credo i wlasnego Communicantes.

Zabrania się Mszy św. czytanej tak wotywnej jak i codziennef za zmarlych.

Wigilia Zesłania Ducha św., pozostaje ber zmiany.

18. Dni zniesionych oktaw: Bożego Ciala i Serca P. Jezusa - stają się feriami ,per annum".

19. W oficjach niedzielnych, które przypadały podczas oktaw Bożego Ciała i Serca P. Jezusa - nic się nie zmienia.

d) Uroczystości świętych:

20. Uroczystości świętych, które dotychczas mialy ryt pólzdwojony zniesione zostaly do rytu prostego.

21. Zaś uroczystości tych świętych, które dotychczas byly rytu prostego, zostały ograniczone do samej kommemoracji, bcz lekcji historycznej.

22. Jeżeli wypadnie jakieś święto, które nie jest I lub II klasy, podczas Wielkiego Postu i Męki Pańskiej, począwszy od Srody Popielcowej, aż do soboty przed Niedzielą Palmową, wówczas tak oficjum (w odmawianiu prýwatnym) jak i Msza św., może być z ferii, lub ze święta.

Tyt. III. Komemoracje.

1. To co powiedziano tutaj o komemoracjach dotycz zarówno oficjum, jak i Mszy św. tak w okurencji, jak i konkurencji.

2. Komemorac ami których się nigdy nie opuszcza i które maja absolutnie pierwszeństwo są:

a) $\mathrm{Z}$ jakiejkolwiek niedzieli,

b) św̧ięta I klasy,

c) ferie W. Postu i Adwentu,

d) ferie i sobota Suchych Dni wrześniowych,

e) Litanie większe.

3. Inne przypadające komemoracje należy tak ułożyć, ażeby liczba ich nie przekraczała trzech. 
4. Oprócz i po komemoracjach wymienionych pod 2) zasadą co do komemoracji jest:

a) W niedzielę I kl., w święta I kl., w ferie i wigilie uprzywilejowane, a ponadto w Mszach śpiewanych lub wotywnych uroczystych, nie dpuszczalna jest żadna komemoracja.

b) W święta II kl. i w pozostałe niedziele, dopuszczalna jest tylko jed́na komemoracja.

c) We wszystkie inne dni czy to ferialne, czy świąteczne -- dopuszczalne są tylko 2 komemoracje.

5. Święta komemorowane nie mają już: a) in officio - wersetu własnego w Prymie i własnej doxologii w hymnach, $\mathrm{z}$ wyjątkiem dni o których w tyt. II, n. 14-17; b) in Missa. Credo i prefacji własnej.

Tyt. IV. Zmiany w brewiarzu

a) Poczqtek i zakończenie godzin kanonicznych.

1. Godziny kanoniczne, tak w publicznym, jak i prywatnym odmawianiu, po opuszczeniu Pater, Ave, ewēntualnie Credo, rozpoczynają się "absolute hoc modo":

Matutinum: od wersetu: „Domine, labia mea aperies. Laudes, Horae minores et Vesperae - od ,Deus, in adiutorium, Completorium - od Jube, domne benedicere.

2. W officjum „Tridui sacri“ i żałobnym - wszystkie godziny kan. po opuszczeniu Pater, Ave, (Credo), - zaczynają się jak jest w brewiarzu.

3. Kończą się zaś godz. kanoniczne w prywatnym i publicznym odmawianu, w ten sposób:

Matutinum (in recitatione privata), Laudes, Tetia, Seksta, Nona. et Vesperae: wersetem „Fidelium animae“. - Prima: błogosławieństwem: Dominus nos benedicat.. Completorium: błogosławieństwem: Benedicat et custodiat.

b) Zakonczenie officium.

4. Codzienne oficjum kończy się Kompletą, oraz odpowiednią antyfoną do Matki Boskiej, do której przywiązane zostały obecnie przywileje i odpusty, które zyskiwało się poprzednio za odmawianie modlitwy "Sacrosanctae."

- Po antyfonie końcowej mówi się werset „Divinum auxilium".

c) Niektóre części brewiarzowe:

3. Hymnów wlasnych, danych świętych $-z$ poszczególnych godzin nie przenosi się.

W hymnie: Iste Confessor - „numquam mutatur tertius versus" i brzmi zawsze: Meruit supremos laudis honores. 
6. Antyfony do Magnificat $w$ ferie siedemdziesiątnicy - jeżeli sa opuszczone - nie przenosi się.

7. Modlitwy feralne, mówi się tylko w Nieszporach i Laudesach oficjów ferialnych, w środy i piątki Adwentu, W. Postu i czasu Męki Pańskiej, jak również w środy, piątki i soboty suchych dni. (Quatuor temporum), z wyjątkiem oktawy Zesłania Ducha św.

8. Wszystkie inne "preces" - opuszcza się.

9. Opuszcza się również „suffragium sanctorum et commemoratio de Cruce".

10. „Symbolum Athanasianum“ - odmawia się tylko w uroczystośe Trójcy św.
d) Inne zmiany.

11. Pierwsze Nieszpory (czy to całe, czy "a capitulo" czy tylko przez kommemorację), przysługują tylko świętom I i II kl. oraz niedzielom.

12. W paszczególnych oficjach należy pamiętać co następuje:

a) $\mathrm{W}$ niedziele i święta I kl. nic się nie zmienia.

b) W święta II kl. i w święta rytu zdwojonego: Pańskie i N. M, P. w Matutinum, Laudesach i Nieszporch ,fit ut in proprio et in communi".

Godziny mniejsze ,ut in psalterio de feria currenti et proprio loco". Completorium de dominica.

c) W pozostałe święta, wigilie, lub ferie, wszystkie godziny kanoniczne jak w psałterzu ,et in proprio loco" - o ile w Matutinum, Laudesach i Nieszporach antyfony i psalmy nie są specjalnie oznaczone.

13. Lekcje "de Scriptura occurenti“ - ze swoimi responsoriami, jeżelí w oznaczonym dniu nie mogą być odmówione, opuszcza się je, także t. zw.- "początki“ (initia librorum).

14. Jezeli w uroczystości świętych nie ma lekcji własnych I nokturnu, bierze się je „de Scriptura occurenti“", a z braku tychże z komunału (de communi).

Tyt. V. Zmiany w msale.

a) Oracje.

1. Modlitwy okresowe (pro diversitate temporum) są zniesione (abolentur).

2. W mszach żałobnych wotywnych - śpiewanych jest tylko jedn oracja. W czytanych mogą być trzy oracje (dici possunt).

8. Oracja „Fidelium“ - jest zniesiona. Obszerniej patrz dekret. 
4. Imperate nakazaną przez Ordynariusza "simpliciter“, opuszcza się wg dotychczasowych zasad, a nadto we wszystkie niedziele i w Mszach śpiewanych, wreszcie jeżeli wg kalendarza liturgicznego odmawia się już 3 oracje.

b) Inne zmiany.

5. „In feriis per annum" — jeżeli przypada wspomnienie jakiegoś świętego Msza św. może być z ferii, lub „de sancto commemorato".

6. W Mszach żalobnych - Selrwencję „Dies irae..." możn opuszczać z wyjątkiem Mszy in die obitus.... praesente vel etiam abesnte cadavere ob rationabilem causam" i w Mszy głównej w Dzień Zaduszny.

7. Credo należy odmawiać $w$ niedziele $\mathrm{i}$ święta I kl. w święta Pańskie, i Matki. Boskiej, święta ,nataliciiss Apostolorum et Ewangelistarum et Doctorum universae Ecclesiae", i w Mszach wotywnych uroczystych śpiewanych.

8. Prefacja jest albo własna, a w braku takiej "de tempore",, lub wspólna.

9. Ostatnia Ewangelia zawsze św. Jana, z wyjątkiem trzeciej Mszy Bożego Narodzenia i Niedzieli Palmowej.

Tłum. Ks. TADEUSZ SZWAGRZYK

\section{WHADOMOSCI LTTURGICZNE:}

Czasopismo liturgiczne „Ephemerides Liturgicae" w tomie LXVIII ezęści czwartej podaje sprawozdanie z III-go zjazdu międzynarodowego studiów liturgicznych odbytego $\mathrm{w}$ Lugano $\mathrm{w}$ Szwajcarii $\mathrm{w}$ dn. 14-18 września $1953 \mathrm{r}$. Pjerwszy miał miejsce w opactwie Maria Laach w Niemczech 1951 roku, drugi zaś w opactwie św. Odylii, blisko Strasburga, w roku 1952.

W Lugano byli obeeni przedstawiciele wszystkich większych centrów liturgicznych z całego swiata, kardynałowie, arcybiskupi, biskupi i opaci z sąsiednich diecezji i opactw z kard. A. Ottaviani ze św. Officjum na czele. Przedstawiciele 13 narodowości w licabie przeszio 100 kaplanów i zakonników brali bardzo żywy udział w obradach i dyskusji. ojciec święty PIUS XII przesłał pismo z życzeniami, na które kongres odpowiedział wyrazami hołdu i synowskiego posłuszenstwa. Źyczenia i pozdrowienia przesłali również Kardynałowie i Biskupi interesujący się sprawami liturgii.

Przez wszystkie dni kongresu w pięknym nowozbudowanym kościele ku czci św. Mikolaja z Flue odprawiali XX. Biskupi pontyfikaine Msze św. przy uczestnictwie wszystkich kaplanów i zakonników ubranych w alby, paski i stuły, śpiewających teksty liturgiczne wobec túumów wiernych

Głównym tematem obrad było czynne uczestnictwo wiernych w liturgii 